\title{
Diallel Analysis of Chilli Pepper (Capsicum annuum L.) Genotypes for Morphological and Fruit Biochemical Traits
}

\author{
Aiswarya C. S. ${ }^{1}$, Vijeth $\mathbf{S}^{1}$, Sreelathakumary $\mathbf{I}^{1}$ and Prashant Kaushik ${ }^{2,3, *}$ \\ 1 Department of Vegetable Science, College of Agriculture, Kerala Agricultural University, Thrissur, \\ Kerala 680656, India; aiswaryachandrasenannair2@gmail.com (A.C.S.); vijet129@gmail.com (V.S.); \\ sreelatha.i@kau.in (S.I.) \\ 2 Instituto de Conservación y Mejora de la Agrodiversidad Valenciana, Universitat Politècnica de València, \\ 46022 Valencia, Spain \\ 3 Nagano University, 1088 Komaki, Ueda, Nagano 386-0031, Japan \\ * Correspondence: prakau@doctor.upv.es; Tel.: +34-963-877000
}

Received: 11 November 2019; Accepted: 17 December 2019; Published: 18 December 2019

check for updates

\begin{abstract}
Chilli pepper is commercially cultivated as a spice and is also used for the extraction of a colouring agent. Here, we performed a diallel genetic study involving five chilli pepper varieties. Parents and their hybrid were evaluated for fifteen morphological and five biochemical traits over two crop seasons under open field conditions. Variation was recorded for all of the studied traits. Similarly, significant values for general combining ability (GCA) and specific combining ability (SCA) variance were obtained for all of the traits. The ratio of $\sigma^{2} \mathrm{SCA} / \sigma^{2} \mathrm{GCA}$ indicates that non-additive gene effects were predominant for all the studied traits except for fruits plant ${ }^{-1}$. Based on SCA effects, cross combinations P2 $\times$ P5, and P4 $\times$ P5 were determined excellent for flesh thickness, yield components and vitamin $\mathrm{C}$. These hybrids are recommended for multilocation testing to assess their suitability for commercial cultivation. Overall, this work presents useful information regarding the genetics of important morphological and biochemical traits in chilli pepper.
\end{abstract}

Keywords: chilli pepper; combining ability; diallel; heterosis; capsaicin; oleoresin; ascorbic acid; colour

\section{Introduction}

Chilli pepper (Capsicum annuum L., $2 \mathrm{n}=2 \times=24$ ), belongs to the family Solanaceae. Chilli is an important spice crop with high therapeutic value of its biochemical constituents [1]. Among five cultivated species, Capsicum annuum L. is the most extensively cultivated. Chilli possesses antioxidant therefore nutritional properties, and it is being regularly used in medicine and pharmaceutical industries [2,3]. Globally, chillies occupy an area of 2.75 million ha with a production of 53.91 million tonnes and productivity of 32.13 tonnes ha ${ }^{-1}$ [4]. Pungency in chilli is because of capsaicinoids, a group of 15 different alkaloids. Capsaicin and dihydrocapsaicin are the major alkaloids which contribute up to $90 \%$ of the total capsaicinoids [5]. The red colour in chilli pepper is mainly due to the significant presence of colouring compounds, namely capsanthin and capsorubin, collectively known as oleoresin. It is an oil-soluble extract and is primarily being used as a colouring and flavouring agent in food products $[6,7]$. Oleoresin is extensively used in meat processing, beverage, pharmaceutical and cosmetic industries as a substitute for the synthetic colour used in food and cosmetic industries $[8,9]$.

Ascorbic acid is an antioxidant that plays a vital role in human nutrition and body functioning. Assessing the quality of chilli pepper colour value is among the principal criteria. Ascorbic acid is actively involved in neutralising free radicals, iron assimilation, wound healing process, and protecting the skin from viral and bacterial infection by building collagen in the skin $[10,11]$. Similarly, 
according to recent reports, capsaicin induces vigorous anticancer activity, particularly against prostate cancer $[12,13]$. In chilli, the hybrid seed production mainly relies on the hand emasculation. Although there are several reports of employing cytoplasmic male sterility (CMS) and genetic male sterility (GMS) in the chilli pepper, the system is still in the early phase of development. Moreover, when employing GMS for hybrid seed production, the segregation into male sterile and male fertile plants is commonly noticed, as is the difficulty of rouging plants with fertile pollens [14].

Moreover, the genetics of chilli pepper are not well studied as compared to other members of Solanaceae [15-17]. Therefore, many concentrated efforts are necessary to develop improved quality hybrids with high yield. The ability of parents to perform better in a hybrid combination depends on the genes, which cannot be merely adjudged by per se performance of the parents [18]. For the selection of parents, combining ability is considered as the essential criterion [19]. Chilli offers much scope of improvement with respect to quality and yield traits through heterosis breeding, which can further be utilised for the development of desirable recombinants [20]. The diallel mating design is commonly used by the plant breeders to determine the bases of inheritance of quantitative traits Among the various schemes of a diallel mating design, the halfway diallel cross (Method II, Model I) is more manageable, as it includes one-directional crosses as compared to the doubled crosses in a full diallel mating scheme [21]. A diallel study is a useful tool for preliminary evaluation of genetic stock for use in hybridisation programme, and to identify superior general as well as specific combiners [22]. Therefore, the present investigation assessed the extent of heterosis in desirable direction and gene action necessary for quality parameters to identify good general and specific combiners and to design the breeding strategy for the genetic improvement of yield and quality traits.

\section{Results}

\subsection{Analysis of Variance for the Experimental Design}

Mean squares owing to parents, hybrids and parents versus hybrids were highly significant for all traits (Table 1). Similarly, the pooled analysis of variance over two seasons for morphological (15) and fruit biochemical (5) traits showed that mean squares due to general combining ability (GCA) and specific combining ability (SCA) were highly significant for all studied traits $(p \leq 0.01)$ (Table 2). The results also indicate the involvement of both additive and non-additive genetic variance in governing the expression of the studied traits. The magnitude of SCAs were high for fruits plant ${ }^{-1}$, seeds fruit ${ }^{-1}$, green fruit yield plant ${ }^{-1}$, dry fruit yield plant ${ }^{-1}$, yield plot $^{-1}$, capsaicin and ascorbic acid. For the remaining traits, the magnitude of GCAs were maximum (Table 2). The values of $\sigma^{2}$ SCA were higher for all the studied traits except for fruits plant $^{-1}$. Non-additive gene effects played a significant role in the inheritance of these traits (Table 2). For fruits plant ${ }^{-1}$, the value of $\sigma^{2}$ GCA was highest, indicating the predominance of additive gene effects (Table 2). \%The ratio of $\sigma^{2} \mathrm{SCA} / \sigma^{2}$ GCA suggests the nature of inheritance for a particular trait and its values were larger $(>1)$ for all of the traits except for fruits plant $^{-1}$ (Table 2). 
Table 1. Analysis of variance of parents, hybrids and parents vs. hybrids.

\begin{tabular}{|c|c|c|c|c|c|c|}
\hline Source of Variation & Replicates & Treatments & Parents & Hybrids & Parents vs. Hybrids & Error \\
\hline d.f & 2 & 14 & 4 & 9 & & 32 \\
\hline Plant height $(\mathrm{cm})$ & 31.33 & $218.16^{* *}$ & $575.20 * *$ & $59.96^{* *}$ & $153.66^{* *}$ & 14.18 \\
\hline Primary branches plant- 1 & 0.04 & $1.52^{* *}$ & $1.86^{* *}$ & $1.69^{* *}$ & $0.36^{* *}$ & 0.02 \\
\hline Days to first flower & 0.05 & $13.08^{* *}$ & $0.81^{* *}$ & $4.29 * *$ & $73.91^{* *}$ & 0.02 \\
\hline Days to first harvest & 0.01 & $12.80 * *$ & $0.56^{* *}$ & $4.29^{* *}$ & $71.49^{* *}$ & 0.02 \\
\hline Fruits plant- 1 & 49.85 & $4565.15^{* *}$ & $378.71^{* *}$ & $4191.18^{* *}$ & $24,308.19^{* *}$ & 32.25 \\
\hline Fruit length $(\mathrm{cm})$ & 0.04 & $6.96^{* *}$ & $3.92 * *$ & $2.28^{* *}$ & $26.94^{* *}$ & 0.41 \\
\hline Fruit girth $(\mathrm{cm})$ & 0.32 & $1.88^{* *}$ & $0.76^{* *}$ & $0.50 * *$ & $0.11^{*}$ & 0.02 \\
\hline Fruit weight (g) & 0.19 & $30.77^{* *}$ & $2.51^{* *}$ & $10.47^{* *}$ & $28.97^{* *}$ & 0.15 \\
\hline Flesh thickness (mm) & 0.98 & $0.66 * *$ & $0.34 * *$ & $0.25^{* *}$ & $0.07^{* *}$ & 2.30 \\
\hline Flesh to seed ratio & 0 & $14.37^{* *}$ & 11.50 ** & $10.00 * *$ & $1.07^{* *}$ & 0 \\
\hline Seeds fruit- 1 & 1.19 & $1932.53 * *$ & $610.69 * *$ & $589.25 * *$ & $13,138.21 * *$ & 10.49 \\
\hline Green fruit yield plant-1 (g) & 594.46 & $132,993.00 * *$ & $15,711.40^{* *}$ & $90,901.51^{* *}$ & $1,085,263.25 * *$ & 901.3 \\
\hline Dry fruit yield plant- $1(\mathrm{~g})$ & 14.82 & $3568.28 * *$ & $418.91 * *$ & $2442.97 * *$ & $29,087.32 * *$ & 24.2 \\
\hline Yield plot-1 (kg) & 0.49 & $110.28^{* *}$ & $13.03^{* *}$ & $75.37^{* *}$ & $900.22 * *$ & 0.75 \\
\hline Driage $(\%)$ & 0.07 & $25.87^{* *}$ & $6.07 * *$ & $27.23^{* *}$ & 0.53 & 0.19 \\
\hline Seed yield fruit-1 (g) & 0.5 & $0.11^{* *}$ & $0.08^{* *}$ & $0.09^{* *}$ & $0.00 * *$ & 2.0 \\
\hline Capsaicin $(\%)$ & 0 & $0.06^{* *}$ & $0.00 * *$ & $0.00 * *$ & $0.88^{* *}$ & 1.37 \\
\hline Oleoresin $(\%)$ & 0.31 & $21.11^{* *}$ & $5.49^{* *}$ & $26.45^{* *}$ & $63.13^{* *}$ & 0.07 \\
\hline Ascorbic acid (mg/100g) & 0.14 & $332.59 * *$ & $8.40 * *$ & $232.22 * *$ & $2270.04 * *$ & 0.66 \\
\hline Colour (ASTA units) & 0.18 & $1154.62 * *$ & $1245.60 * *$ & $913.54 * *$ & $1537.60 * *$ & 0.44 \\
\hline
\end{tabular}


Table 2. Pooled Analysis of variance over two crop seasons for general combining ability (GCA) and specific combining ability (SCA) for the fifteen morphological and five biochemical descriptors in chilli pepper.

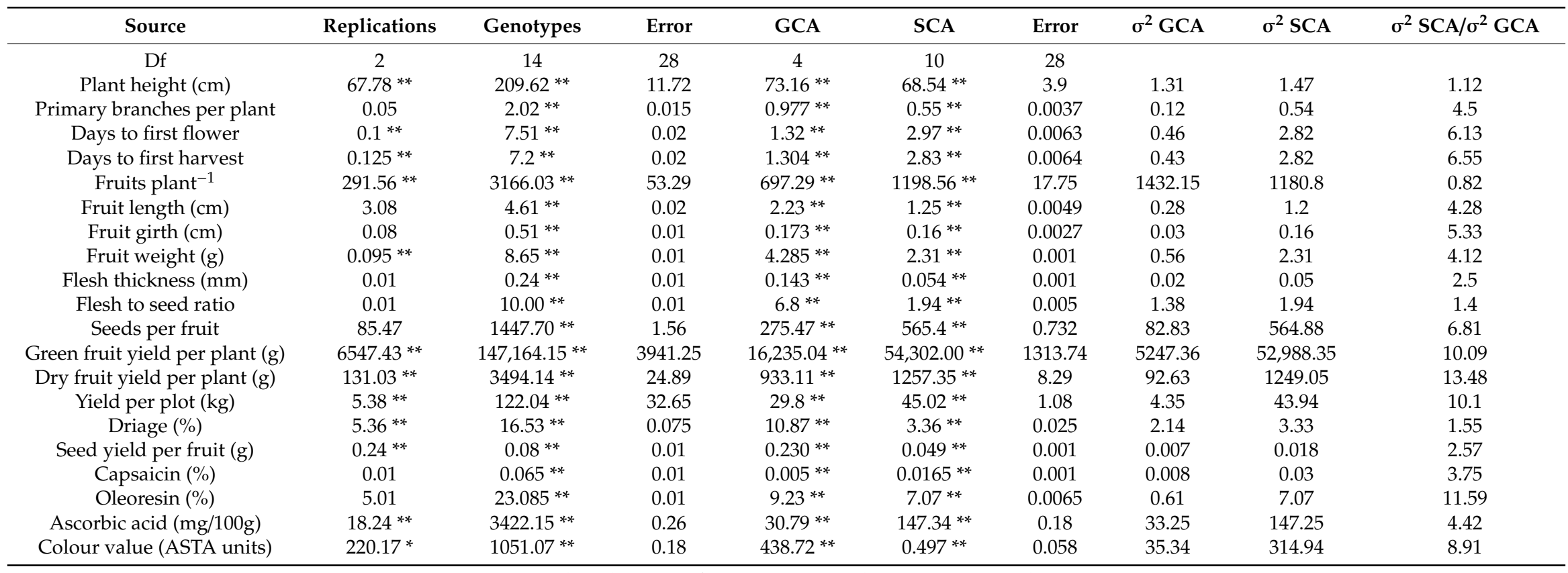

** and * indicate significant at $p<0.01$ and $p<0.05$, respectively. 


\subsection{GCA and SCA Effects}

The combining ability analysis showed that parent P5 expressed high GCA effects for fruits plant $^{-1}$, fruit weight and green fruit yield plant ${ }^{-1}$ (Table 3). Besides, it also exhibited significant and positive GCA values for flesh thickness, flesh to seed ratio, driage, oleoresin and colour value (Table 3). Parents P1, P2 and P3 had significant negative values for fruit traits and yield components (Table 3). Parent P3 expressed high positive considerable GCA effects for days to first flower and days to first harvest (Table 3). Parent P2 had a significant positive value for ascorbic acid while this parent had negative values for yield components. For fruit length, flesh thickness seeds plant ${ }^{-1}$ and capsaicin, parent P1 expressed high GCA effects (Table 3).

Table 3. General combining ability (GCA) effects for fifteen morphological and five biochemical traits of chilli pepper.

\begin{tabular}{|c|c|c|c|c|c|}
\hline Traits & P1 & $\mathbf{P 2}$ & P3 & $\mathbf{P 4}$ & P5 \\
\hline Plant height $(\mathrm{cm})$ & $-4.6^{* *}$ & $-1.4^{*}$ & $3.17^{* *}$ & $2.87^{* *}$ & 0.13 \\
\hline Primary branches plant ${ }^{-1}$ & $-0.49 * *$ & $0.14^{* *}$ & $-0.25 * *$ & $0.16^{* *}$ & $-0.43 * *$ \\
\hline Days to first flower & $-0.075^{* *}$ & $-0.15^{* *}$ & $0.64 * *$ & $-0.525^{* *}$ & $-0.085^{* *}$ \\
\hline Days to first harvest & $-0.09 * *$ & $-0.155^{* *}$ & $0.63^{* *}$ & $-0.515^{* *}$ & $-0.1^{* *}$ \\
\hline Fruits plant ${ }^{-1}$ & $-8.77 * *$ & $-8.05 * *$ & $8.44 * *$ & $-3.87^{* *}$ & $9.09 * *$ \\
\hline Fruit length $(\mathrm{cm})$ & $1.46^{* *}$ & $-0.40 * *$ & $-0.64 * *$ & $-0.06^{* *}$ & $0.37 * *$ \\
\hline Fruit girth $(\mathrm{cm})$ & $0.04 *$ & $0.48^{* *}$ & $0.15^{* *}$ & $0.05 * *$ & $0.25 * *$ \\
\hline Fruit weight (g) & $-0.24^{* *}$ & $-0.6^{* *}$ & $-0.79 * *$ & $0.09 * *$ & $1.14^{* *}$ \\
\hline Flesh thickness (mm) & $0.041^{* *}$ & $-0.055^{* *}$ & $-0.037^{* *}$ & $-0.165^{* *}$ & $0.205^{* *}$ \\
\hline Flesh to seed ratio & $0.445^{* *}$ & $-1.16^{* *}$ & $-0.895 * *$ & $0.475 * *$ & $1.125 * *$ \\
\hline Seeds fruit-1 & $9.74 * *$ & $2.14 * *$ & $-4.9 * *$ & $-6.09 * *$ & $-1.58 * *$ \\
\hline Green fruit yield plant ${ }^{-1}(\mathrm{~g})$ & -20.07 & $-76.84 * *$ & -14.49 & 5.83 & $115.56 * *$ \\
\hline Dry fruit yield plant ${ }^{-1}(\mathrm{~g})$ & $-3.78^{* *}$ & $-12.11 * *$ & $-1.96 *$ & $2.09 *$ & $18.71^{* *}$ \\
\hline Yield plot ${ }^{-1}(\mathrm{~kg})$ & $-0.575 *$ & $-2.20 * *$ & $-0.41 *$ & $0.43 *$ & $3.32 * *$ \\
\hline Driage $(\%)$ & 0.085 & $-0.915^{* *}$ & $-0.115 *$ & 0.06 & $2.01 * *$ \\
\hline Seed yield fruit ${ }^{-1}(\mathrm{~g})$ & $-0.04 *$ & $0.085^{* *}$ & $0.061 * *$ & $0.003 *$ & $0.115^{* *}$ \\
\hline Capsaicin (\%) & $0.0045^{* *}$ & $0.001 *$ & $0.0015 *$ & $-0.005^{* *}$ & $-0.002 * *$ \\
\hline Oleoresin (\%) & $0.035 * *$ & $-1.51 * *$ & $-0.28 * *$ & $0.10 * *$ & $1.67 * *$ \\
\hline Ascorbic acid (mg/100g) & $-2.6^{* *}$ & $3.03^{* *}$ & 0.12 & $-1.09 * *$ & $0.54 * *$ \\
\hline Colour value (ASTA units) & $-7.54^{* *}$ & $-5.00 * *$ & $-1.06^{* *}$ & $0.69 * *$ & $12.92 * *$ \\
\hline
\end{tabular}

The SCA values for the cross combinations are presented in Table 4 . The cross combination P1 $\times$ P2 showed high significant positive SCA effects for plant height, primary branches plant ${ }^{-1}$, fruit girth and ascorbic acid content (Table 4). The hybrid combination P2 $\times$ P3 showed the highest SCA effects for days to first flower and days to first harvest (Table 4). The cross combination P4 $\times$ P5 exhibited high positive SCA effects for yield plot $^{-1}$ (Table 4 ). The SCA effects were high and positively significant in hybrid P $2 \times$ P5 for fruit length, fruit weight and seeds fruit ${ }^{-1}$. The hybrid P1 $\times$ P3 showed maximum SCA effects for capsaicin (Table 4).

\subsection{Heterosis}

A significant amount of mid parent heterosis (MPH) was noticed for all studied traits (Table 5). The cross combination P4 $\times$ P5 showed the maximum positive heterosis for the yield plot $^{-1}(142 \%)$ and fruits $_{\text {plant }}{ }^{-1}(103 \%)$ (Table 5). The highest MPH fruit weight was determined in the cross combination P3 $\times$ P5 (58\%). For capsaicin content and colour value, the cross combination P1 $\times$ P3 exhibited the maximum MPH of $82 \%$ and $18 \%$, respectively (Table 5). Similarly, in the case of better parent heterosis $(\mathrm{BPH})$, significant and positive heterosis values were displayed by most of the hybrids (Table 5). Except for the traits days to first flower and days to first harvest for both the traits, none of the hybrid combinations showed positive MPH or BPH values (Table 5). The cross combination P4 $\times$ P5 displayed maximum $\mathrm{BPH}$ for yield and yield contributing traits and the hybrid cross combination $\mathrm{P} 1 \times \mathrm{P} 3$ for the biochemical traits capsaicin and colour value (Table 5). 
Table 4. Specific combining ability (SCA) effects exhibited by ten $\mathrm{F}_{1}$ hybrids for the fifteen morphological and five biochemical traits of chilli pepper.

\begin{tabular}{|c|c|c|c|c|c|c|c|c|c|c|}
\hline Parents & $\mathbf{P} 1 \times \mathbf{P} 2$ & $\mathbf{P 1} \times \mathbf{P 3}$ & $\mathbf{P 1} \times \mathbf{P} 4$ & P1 $\times$ P5 & $\mathbf{P} 2 \times \mathbf{P} 3$ & $\mathbf{P} 2 \times \mathbf{P} 4$ & P2 $\times$ P5 & $\mathbf{P} 3 \times \mathbf{P} 4$ & $\mathrm{P} 3 \times \mathrm{P} 5$ & P4 $\times$ P5 \\
\hline Plant height $(\mathrm{cm})$ & $12.02 * *$ & $2.64 * *$ & $7.74^{* *}$ & 0.74 & $2.54 *$ & -1.18 & $7.31^{* *}$ & -2.28 & $-10.155^{* *}$ & $-4.52 * *$ \\
\hline Primary branches plant ${ }^{-1}$ & $0.87 * *$ & $0.4^{* *}$ & $-0.22 * *$ & $-0.58^{* *}$ & $0.68^{* *}$ & $-0.19^{* *}$ & $0.18^{* *}$ & $-0.66^{* *}$ & $0.87 * *$ & $0.32 * *$ \\
\hline Days to first flower & $-1.52^{* *}$ & $0.30^{* *}$ & $-0.59 * *$ & 0.075 & $0.445^{* *}$ & $-0.995^{* *}$ & $-1.98^{* *}$ & $-2.18^{* *}$ & $-0.77^{* *}$ & $-0.66^{* *}$ \\
\hline Days to first harvest & $-1.52 * *$ & $0.30 * *$ & $-0.59 * *$ & 0.075 & $0.445^{* *}$ & $-0.995^{* *}$ & $-1.98^{* *}$ & $-2.18^{* *}$ & $-0.77 * *$ & $-0.66^{* *}$ \\
\hline Fruits plant ${ }^{-1}$ & $12.26^{* *}$ & $-5.33^{* *}$ & $-7.95 * *$ & $-10.07^{* *}$ & $8.80 * *$ & $-9.91^{* *}$ & $17.05^{* *}$ & $44.35^{* *}$ & $23.12^{* *}$ & $38.18^{* *}$ \\
\hline Fruit length $(\mathrm{cm})$ & $-0.40^{* *}$ & $0.57^{* *}$ & $1.07^{* *}$ & $0.77^{* *}$ & $0.82^{* *}$ & $0.51^{* *}$ & $1.52^{* *}$ & $0.64^{* *}$ & $-0.1 *$ & -0.05 \\
\hline Fruit girth $(\mathrm{cm})$ & $0.55^{* *}$ & $-0.06^{* *}$ & $-0.065^{* *}$ & $0.13^{* *}$ & $-0.17^{* *}$ & $-0.56^{* *}$ & $0.24^{* *}$ & $0.07 *$ & $0.56^{* *}$ & $-0.30 * *$ \\
\hline Fruit weight (g) & $1.19 * *$ & $-0.31^{* *}$ & $0.92 * *$ & $0.075^{* *}$ & $-0.275^{* *}$ & $-0.63^{* *}$ & $1.53^{* *}$ & $-0.77^{* *}$ & $2.15^{* *}$ & $1.44^{* *}$ \\
\hline Flesh thickness (mm) & $-0.095^{* *}$ & $-0.04 * *$ & $0.095^{* *}$ & $-0.155^{* *}$ & $-0.025 * *$ & $0.075 * *$ & $0.15^{* *}$ & $0.15^{* *}$ & $-0.24 * *$ & $0.46^{* *}$ \\
\hline Flesh to seed ratio & $1.035^{* *}$ & $0.53^{* *}$ & $-0.47^{* *}$ & $1.48^{* *}$ & $0.1^{* *}$ & $-0.79 * *$ & $0.075^{* *}$ & $1.45^{* *}$ & $2.22 * *$ & $-0.70 * *$ \\
\hline Seeds fruit ${ }^{-1}$ & $8.20 * *$ & $16.32 * *$ & $15.92 * *$ & $1.20 * *$ & $-9.76^{* *}$ & $12.96^{* *}$ & $33.81 * *$ & $18.90^{* *}$ & $21.32 * *$ & -0.62 \\
\hline Green fruit yield plant ${ }^{-1}(\mathrm{~g})$ & $115.85^{* *}$ & $-25.91 * *$ & $134.48^{* *}$ & $54.53 * *$ & $44.17^{* *}$ & -35.31 & $182.30 * *$ & $172.20 * *$ & $207.80 * *$ & $275.53^{* *}$ \\
\hline Dry fruit yield plant $^{-1}(\mathrm{~g})$ & $22.31 * *$ & -3.95 & $23.17^{* *}$ & $8.24 * *$ & $6.85^{* *}$ & $6.40 * *$ & $29.41 * *$ & $31.85^{* *}$ & $29.83 * *$ & $34.09 * *$ \\
\hline Yield $\operatorname{plot}^{-1}(\mathrm{~kg})$ & $3.97 * *$ & -0.73 & $3.85 * *$ & $1.56^{*}$ & 1.27 & -1.01 & $5.24 * *$ & $4.96 * *$ & $5.97^{* *}$ & $7.93 * *$ \\
\hline Driage $(\%)$ & $-0.62^{* *}$ & $-2.32 * *$ & $1.42 * *$ & $-0.2 *$ & $0.315^{* *}$ & $-2.83^{* *}$ & $1.38^{* *}$ & $-0.62 * *$ & $2.14^{* *}$ & $1.48^{* *}$ \\
\hline Seed yield fruit- $1(\mathrm{~g})$ & $-0.03^{* *}$ & $0.005 *$ & $0.04 * *$ & $-0.03^{* *}$ & $-0.02 * *$ & $0.02 * *$ & $0.06^{* *}$ & $0.09^{* *}$ & $-0.17^{* *}$ & $0.12 * *$ \\
\hline Capsaicin (\%) & $0.07^{* *}$ & $0.115^{* *}$ & $0.10^{* *}$ & $0.07^{* *}$ & $0.15^{* *}$ & $0.07^{* *}$ & $0.11^{* *}$ & $0.09 * *$ & $0.06^{* *}$ & $0.09 * *$ \\
\hline Oleoresin $(\%)$ & $-1.30^{* *}$ & $2.27 * *$ & $0.91 * *$ & 1.35 ** & $-2.21 * *$ & $0.52 * *$ & $3.82 * *$ & $3.23 * *$ & $-0.42 * *$ & $1.63^{* *}$ \\
\hline Ascorbic acid (mg/100g) & $13.90^{* *}$ & $12.4^{* *}$ & $-1.53^{* *}$ & $-10.68^{* *}$ & $3.09^{* *}$ & $1.98 * *$ & $11.83^{* *}$ & $-0.59 * *$ & $8.24^{* *}$ & $13.47^{* *}$ \\
\hline Colour value (ASTA units) & $-0.86^{* *}$ & $16.42 * *$ & $21.50 * *$ & $13.77 * *$ & $-3.10 * *$ & $-9.15^{* *}$ & $25.63 * *$ & $-20.27^{* *}$ & $-2.56 * *$ & $-0.29 *$ \\
\hline
\end{tabular}

** and * indicate significant at $p<0.01$ and $p<0.05$, respectively. 
Table 5. Mid parent heterosis (MPH) and better parent heterosis (BPH) values (\%) for the morphological and biochemical traits in the chilli pepper hybrids.

\begin{tabular}{|c|c|c|c|c|c|c|c|c|c|c|c|}
\hline Traits & MPH/BPH & $\mathbf{P 1} \times \mathbf{P} 2$ & $\mathbf{P 1} \times \mathbf{P 3}$ & P1 $\times$ P4 & P1 × P5 & $\mathbf{P} 2 \times \mathbf{P 3}$ & $\mathbf{P} 2 \times \mathbf{P} 4$ & $\mathrm{P} 2 \times \mathrm{P} 5$ & $\mathbf{P 3} \times \mathbf{P 4}$ & P3 $\times$ P5 & P4 $\times$ P5 \\
\hline \multirow{2}{*}{ Plant height $(\mathrm{cm})$} & MPH & $36.62 * *$ & $8.68 *$ & $18.87^{* *}$ & 7.01 & $7.73 *$ & 5.98 & 15.37 ** & $-6.52 *$ & $-17.05^{* *}$ & $-8.04 *$ \\
\hline & $\mathrm{BPH}$ & $29.14^{* *}$ & $-10.45^{* *}$ & -0.24 & $-8.59 *$ & -6.94 & -6.63 & 3.59 & $-8.62 *$ & $-20.59 * *$ & $-9.98 *$ \\
\hline \multirow{2}{*}{ Primary branches per plant } & MPH & $64.56^{* *}$ & $45.21^{* *}$ & 0 & $-13.73 * *$ & $72.15^{* *}$ & $27.36^{* *}$ & $31.48^{* *}$ & $-6.00 *$ & $45.10^{* *}$ & $13.18^{* *}$ \\
\hline & $\mathrm{BPH}$ & $52.94^{* *}$ & $45.21^{* *}$ & $-21.26^{* *}$ & $-32.82^{* *}$ & $60.00^{* *}$ & $6.30^{* *}$ & $8.40^{* *}$ & $-25.98^{* *}$ & $12.98^{* *}$ & $11.45^{* *}$ \\
\hline \multirow{2}{*}{ Days to first flower } & MPH & $-9.73 * *$ & -0.6 & $-8.33 * *$ & $-4.26^{* *}$ & $-2.24 * *$ & $-10.14 * *$ & $-12.85 * *$ & $-12.96 * *$ & $-7.80^{* *}$ & $-9.31 * *$ \\
\hline & $\mathrm{BPH}$ & $-11.03^{* *}$ & $-3.49^{* *}$ & $-9.00 * *$ & $-5.53^{* *}$ & $-3.72 * *$ & $-10.79 * *$ & $-12.95^{* *}$ & $-14.88^{* *}$ & $-9.30^{* *}$ & $-9.86^{* *}$ \\
\hline \multirow{2}{*}{ Days to first harvest } & MPH & $-5.75^{* *}$ & -0.36 & $-4.48^{* *}$ & $-2.52 * *$ & $-1.34^{* *}$ & $-5.87^{* *}$ & $-7.63^{* *}$ & $-6.88^{* *}$ & $-4.66^{* *}$ & $-5.38^{* *}$ \\
\hline & $\mathrm{BPH}$ & $-6.55^{* *}$ & $-2.10^{* *}$ & -4.76 ** & $-3.28^{* *}$ & $-2.24 * *$ & $-6.41 * *$ & $-7.69 * *$ & $-8.25 * *$ & $-5.59^{* *}$ & $-5.85^{* *}$ \\
\hline \multirow{2}{*}{ Fruits per plant } & MPH & $40.67^{* *}$ & 16.51 * & $64.55^{* *}$ & $48.70 * *$ & $52.26^{* *}$ & $89.79 * *$ & $76.94 * *$ & $71.74 * *$ & $46.34^{* *}$ & 103.12 ** \\
\hline & $\mathrm{BPH}$ & $24.14 *$ & 11.54 & $34.25^{* *}$ & $43.34 * *$ & $29.39^{* *}$ & $73.26^{* *}$ & $61.40^{* *}$ & $35.48^{* *}$ & $35.27^{* *}$ & $70.69^{* *}$ \\
\hline \multirow{2}{*}{ Fruit length $(\mathrm{cm})$} & MPH & $8.05 * *$ & $16.09^{* *}$ & $20.46^{* *}$ & $16.89 * *$ & $23.53^{* *}$ & $18.51^{* *}$ & $30.20 * *$ & $21.54^{* *}$ & $14.91 * *$ & $12.48^{* *}$ \\
\hline & $\mathrm{BPH}$ & $-3.95 * *$ & $1.35 *$ & $11.13^{* *}$ & $12.49^{* *}$ & $21.01^{* *}$ & $13.80^{* *}$ & $19.87^{* *}$ & $14.43 * *$ & $3.82^{* *}$ & $7.64^{* *}$ \\
\hline \multirow{2}{*}{ Fruit girth $(\mathrm{cm})$} & MPH & $22.24^{* *}$ & $5.00 *$ & $-4.91 *$ & $14.52 * *$ & -3.16 & $-19.56^{*}$ & $10.04^{* *}$ & -2.81 & $20.02 * *$ & $-7.70 * *$ \\
\hline & $\mathrm{BPH}$ & $18.02 * *$ & 4.31 & $-13.73^{* *}$ & $5.68 *$ & $-7.10^{* *}$ & $-24.59 *$ & $5.00 *$ & $-12.34^{* *}$ & $10.09 * *$ & $-9.40 * *$ \\
\hline \multirow{2}{*}{ Fruit weight (g) } & MPH & $45.50 * *$ & 10.16 & $22.00 * *$ & $26.40 * *$ & 7.53 & 4.5 & $56.18 * *$ & 12.37 & $58.89^{* *}$ & $42.93^{* *}$ \\
\hline & $\mathrm{BPH}$ & $23.47^{* *}$ & -2.01 & $22.00 * *$ & $25.42 * *$ & 1.89 & -11.32 & $31.69^{* *}$ & -0.05 & $40.38^{* *}$ & $41.82 * *$ \\
\hline \multirow{2}{*}{ Flesh thickness (mm) } & MPH & $-5.22 * *$ & $-2.44^{* *}$ & $16.23 * *$ & $-3.58^{* *}$ & 0.23 & $15.23^{* *}$ & $9.05^{* *}$ & $24.36^{* *}$ & $-6.11^{* *}$ & $29.42 * *$ \\
\hline & $\mathrm{BPH}$ & $-11.03^{* *}$ & $-6.21 * *$ & $-7.72 * *$ & $-5.56^{* *}$ & $-2.24^{* *}$ & $-3.77^{* *}$ & 0.4 & $1.79^{*}$ & $-11.51^{* *}$ & 1.19 \\
\hline \multirow{2}{*}{ Flesh to seed ratio } & MPH & $44.46^{* *}$ & $33.44 * *$ & $4.60^{* *}$ & $44.77^{* *}$ & $7.50 * *$ & $-13.72 * *$ & 0.98 & $26.08 * *$ & $-32.73^{* *}$ & $-11.09 * *$ \\
\hline & $\mathrm{BPH}$ & $22.80 * *$ & $18.22 * *$ & $-10.21 * *$ & $16.59^{* *}$ & $2.50 *$ & $-35.21 * *$ & $-27.92 * *$ & $-2.09 * *$ & $-50.51 * *$ & $-17.67^{* *}$ \\
\hline \multirow{2}{*}{ Seeds per fruit } & MPH & $27.54^{* *}$ & $39.46 * *$ & $40.30 * *$ & $26.15 * *$ & $13.10^{* *}$ & $40.99 * *$ & $65.50 * *$ & $53.21 * *$ & $55.64^{* *}$ & $33.00 * *$ \\
\hline & $\mathrm{BPH}$ & $18.82 * *$ & $21.52 * *$ & $18.35^{* *}$ & $9.47^{* *}$ & $5.21 * *$ & $26.60^{* *}$ & $53.26^{* *}$ & $47.46^{* *}$ & $54.88^{* *}$ & $28.61 * *$ \\
\hline \multirow{2}{*}{ Green fruit yield per plant $(\mathrm{g})$} & MPH & $91.13^{* *}$ & $29.48 *$ & $102.18^{* *}$ & 70.33 ** & $66.86^{* *}$ & $89.75^{* *}$ & 113.31 ** & $99.72 * *$ & $90.86^{* *}$ & $142.70^{* *}$ \\
\hline & $\mathrm{BPH}$ & $52.38^{* *}$ & 26.41 & $73.27^{* *}$ & $65.57^{* *}$ & $35.50 *$ & $73.87^{* *}$ & $66.51^{* *}$ & $74.70^{* *}$ & $81.25^{* *}$ & $103.14^{* *}$ \\
\hline \multirow{2}{*}{ Dry fruit yield per plant (g) } & MPH & $91.23 * *$ & $29.86^{* *}$ & $102.79^{* *}$ & $55.16 * *$ & $64.66^{* *}$ & $86.82 * *$ & $90.77^{* *}$ & $104.17^{* *}$ & $64.75^{* *}$ & $88.76^{* *}$ \\
\hline & $\mathrm{BPH}$ & $52.95 * *$ & $27.62 * *$ & $73.59 * *$ & $40.38^{* *}$ & $33.47^{* *}$ & $72.08^{* *}$ & $41.69^{* *}$ & $77.38^{* *}$ & $46.75^{* *}$ & $48.78^{* *}$ \\
\hline \multirow{2}{*}{ Yield per plot (kg) } & MPH & $91.20 * *$ & $29.65 *$ & $101.91 * *$ & $70.35 * *$ & $67.14^{* *}$ & $89.81 * *$ & 113.35 ** & $100.00 * *$ & $91.04^{* *}$ & $142.76^{* *}$ \\
\hline & $\mathrm{BPH}$ & $52.42 * *$ & 26.43 & $73.03 * *$ & $65.58^{* *}$ & $35.84 *$ & $73.92 * *$ & $66.53 * *$ & $75.12 * *$ & $81.21 * *$ & $103.18^{* *}$ \\
\hline \multirow{2}{*}{ Driage (\%) } & MPH & $-5.79 * *$ & $-12.94 * *$ & 2.32 & 1.88 & -1.93 & $-14.89 * *$ & $6.21^{* *}$ & $-3.91 * *$ & $10.13^{* *}$ & $7.29 * *$ \\
\hline & $\mathrm{BPH}$ & $-9.45^{* *}$ & $-18.07^{* *}$ & 0.54 & 0.57 & $-4.06^{* *}$ & $-16.78^{* *}$ & 0.83 & $-8.04 * *$ & 2.4 & $4.10^{* *}$ \\
\hline \multirow{2}{*}{ Seed yield per fruit (g) } & MPH & $-13.56^{* *}$ & $-8.00 * *$ & $-1.71 *$ & $-64.64 * *$ & -0.42 & $6.15^{* *}$ & $12.53^{* *}$ & $-7.91^{* *}$ & $34.28 * *$ & $31.41 * *$ \\
\hline & $\mathrm{BPH}$ & $-18.73^{* *}$ & $-9.61^{* *}$ & $-9.05^{* *}$ & $-72.40 * *$ & $-4.78^{* *}$ & $-7.17^{* *}$ & $-15.94 * *$ & $-16.16^{* *}$ & $3.49^{* *}$ & $9.04 * *$ \\
\hline
\end{tabular}


Table 5. Cont.

\begin{tabular}{|c|c|c|c|c|c|c|c|c|c|c|c|}
\hline Traits & MPH/BPH & $\mathbf{P 1} \times \mathbf{P} 2$ & $\mathbf{P 1} \times \mathbf{P 3}$ & $\mathrm{P} 1 \times \mathbf{P} 4$ & P1 × P5 & $\mathbf{P} 2 \times \mathbf{P} 3$ & P2 $\times$ P4 & $\mathbf{P} 2 \times \mathbf{P} 5$ & P3 $\times$ P4 & P3 $\times$ P5 & $\mathbf{P} 4 \times \mathbf{P} 5$ \\
\hline \multirow{2}{*}{ Capsaicin (\%) } & MPH & $64.12 * *$ & $82.03 * *$ & $66.79^{* *}$ & $56.46^{* *}$ & $88.80^{* *}$ & $62.93 * *$ & $69.06^{* *}$ & 72.33 ** & $62.93 * *$ & $60.45^{* *}$ \\
\hline & $\mathrm{BPH}$ & $60.45^{* *}$ & $73.88^{* *}$ & $64.93^{* *}$ & $54.74^{* *}$ & $84.38^{* *}$ & $61.07^{* *}$ & $63.50 * *$ & $66.41 * *$ & $54.01 * *$ & $56.93^{* *}$ \\
\hline \multirow{2}{*}{ Oleoresin $(\%)$} & MPH & $-15.79 * *$ & $26.58^{* *}$ & $23.68^{* *}$ & $24.71^{* *}$ & $-12.33^{* *}$ & $17.14^{* *}$ & $41.77^{* *}$ & 45.21 ** & 14.63 ** & $37.47^{* *}$ \\
\hline & $\mathrm{BPH}$ & $-21.95^{* *}$ & $21.95 * *$ & $14.63^{* *}$ & $20.45^{* *}$ & $-15.79 * *$ & $17.14^{* *}$ & $27.27^{* *}$ & 39.47 ** & 6.82 & $23.41^{* *}$ \\
\hline \multirow{2}{*}{ Ascorbic acid (mg/100 g) } & MPH & $26.89 * *$ & 23.60 ** & $6.21 * *$ & $-3.17 * *$ & $18.26^{* *}$ & $14.43 * *$ & $26.96^{* *}$ & $9.35^{* *}$ & $21.95^{* *}$ & $24.23 * *$ \\
\hline & ВРH & $25.69 * *$ & $23.56^{* *}$ & $4.66^{* *}$ & $-3.64 * *$ & $17.10^{* *}$ & $13.83 * *$ & $26.37^{* *}$ & $7.71^{* *}$ & $21.32 * *$ & $23.00 * *$ \\
\hline \multirow{2}{*}{ Colour value (ASTA units) } & MPH & $11.20^{* *}$ & $18.60^{* *}$ & $22.42 * *$ & $24.53 * *$ & $-1.52 * *$ & $-5.24 * *$ & $24.03 * *$ & $-15.11^{* *}$ & $2.25^{* *}$ & $3.90^{* *}$ \\
\hline & BPH & $1.84^{* *}$ & $2.92 * *$ & $5.55^{* *}$ & $6.80^{* *}$ & $-7.21 * *$ & $-11.36^{* *}$ & $15.35^{* *}$ & $-15.76^{* *}$ & $0.84^{* *}$ & $3.25 * *$ \\
\hline
\end{tabular}

** and * indicate significant at $p<0.01$ and $p<0.05$, respectively. 


\subsection{Correlations}

Among the parents, seventeen correlations were observed to be significant $(p<0.05)$ (Figure 1). There were three absolute negative correlations $(\geq 0.9)$ and the remaining were positive correlations (Figure 1). Seeds per fruit were negatively correlated with the plant height and colour value. Yield per plot was absolutely correlated with dry fruit weight, green fruit yield, and oleoresin content (Figure 1). In parents, capsaicin content was significantly correlated with fruit weight and driage (Figure 1). In the case of hybrids, thirty-three correlations were determined to be significant $(p<0.05)$ (Figure 2). There were in total eight absolute correlations (Figure 2). Among hybrids, the flesh to seed ratio was determined to be negatively correlated with the seed yield per fruit and primary branches per plant. Interestingly, among hybrids yield per plot was determined to be correlated with fruit weight, flesh thickness and driage (Figure 2). Concerning hybrids, the colour value was correlated with fruit weight and driage. In addition, the capsaicin content was not correlated with any other trait (Figure 2).

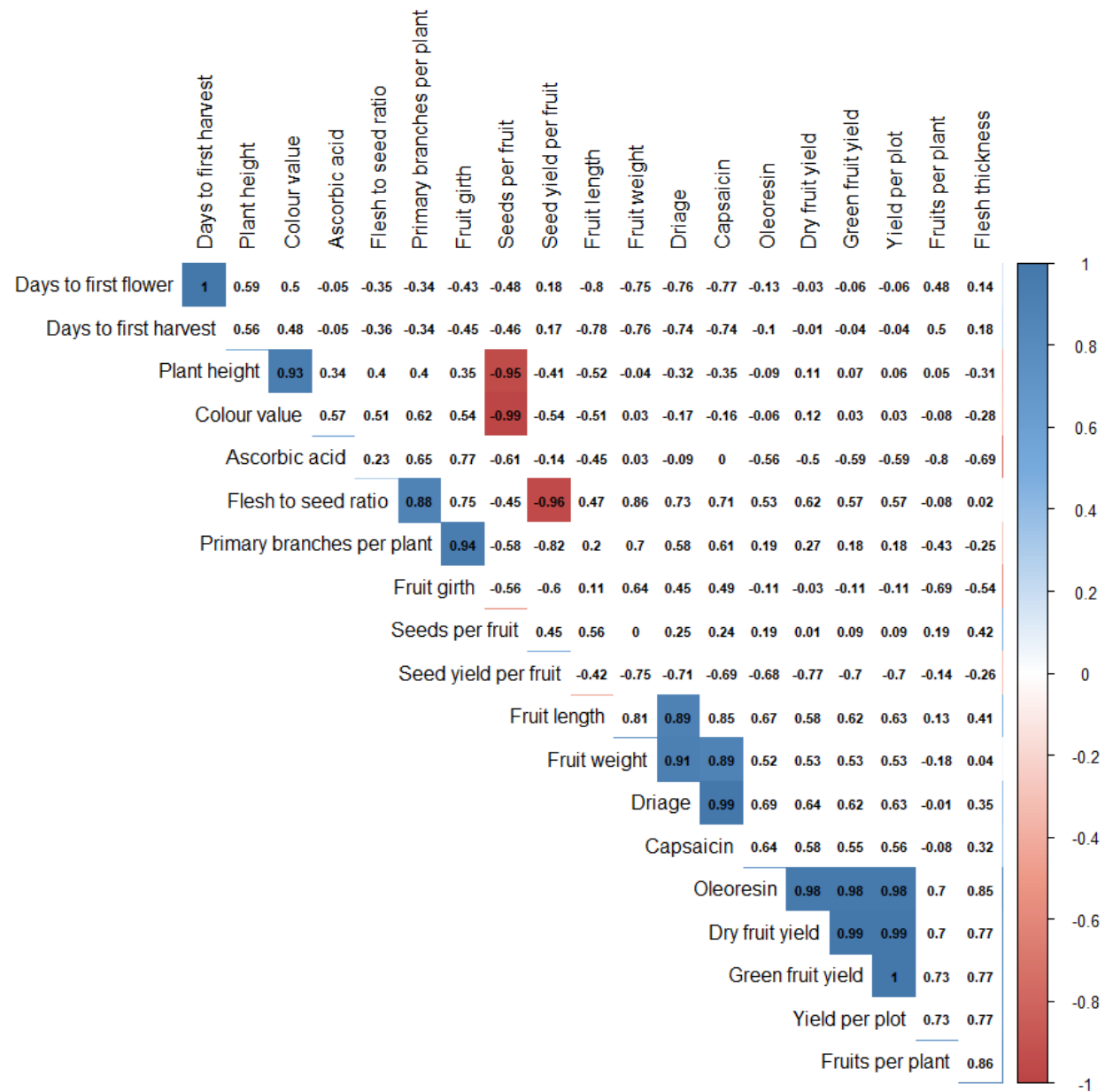

Figure 1. Pearson's correlation coefficients of parental lines of chilli pepper with significant values $p<0.05$ highlighted. 


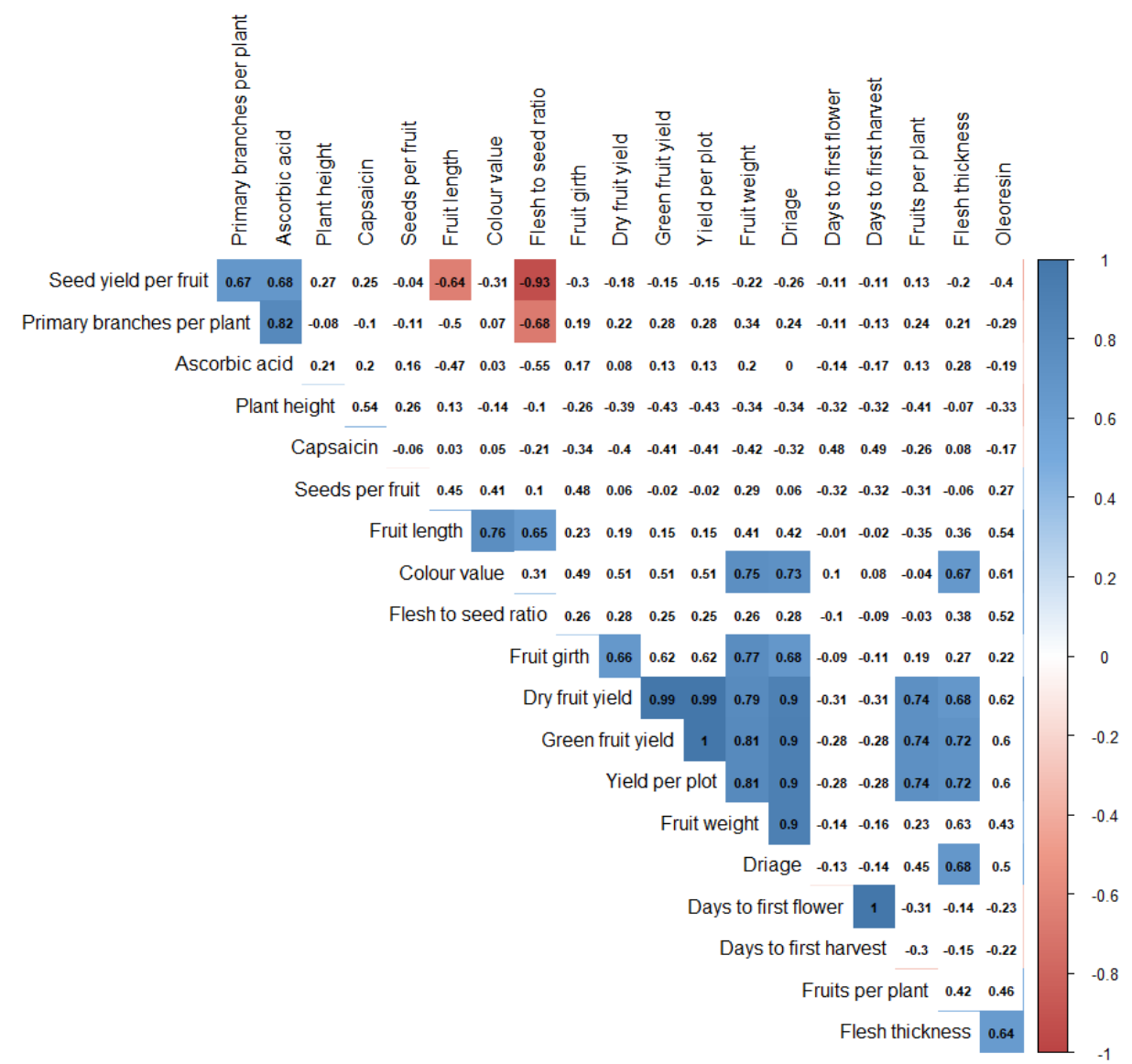

Figure 2. Pearson's correlation coefficients of hybrids of chilli pepper with significant values $p<0.05$ highlighted.

\section{Discussion}

Chilli pepper improvement is crucial for securing the higher yield of this crop. We found highly significant differences for all studied traits. Significant differences among chilli pepper genotypes were also reported [23-27]. In the present study, the GCA and SCA variance was significant $(p \leq 0.01)$ for all studied traits. This suggested the influence of both additive and non-additive gene effects on hybrid performance. The inheritance of a particular trait could be identified based on the ratio of GCA and SCA variance [28]. The non-additive gene effects played a significant role than additive effects in all studied traits except fruits plant ${ }^{-1}$. Previously, in chilli pepper, Hasanuzzaman et al. [29] reported the non-additive genetic control of plant height. Bhutia et al. [30] also observed non-additive gene effects for primary branches plant ${ }^{-1}$, days to first flower, fruit length, fruit girth and seeds fruit ${ }^{-1}$.

Heterosis breeding provides an opportunity to increase productivity in chilli pepper. The primary objective of heterosis is to achieve high yield potential and good quality aspects of the crop plants [31]. Commercial hybrids are becoming more popular than the open-pollinated cultivars because of superiority in yield and quality traits. Hybrids are becoming popular in many crops as they give an opportunity to utilise the synergistic effect of a genetic combination [32]. For a systematic breeding program, it is essential to identify the parents as well as crosses to bring genetic improvement in economic character. The magnitude of heterosis depends on the genetic diversity existing between the parents [33]. In a crop such as chilli pepper, where there is evidence for polygenic action determining the yield and the yield components, the choice of parents must be based on refined biometrical techniques. The value of genotypes depends on the ability to produce superior hybrids in combination with other genotypes [34]. 
The traits with higher GCA/SCA values possess a chiefly additive genetic control. In contrast, the traits with low GCA/SCA ration have a predominantly non-additive genetic control $[35,36]$. In our study, the predominance of SCA could be due to less diversity among the parents. This infers that breeding for yield and its contributing traits will not only require parents holding higher GCA values, in addition to specific hybrid combinations that will result in the expression of the trait. The present results are also in accordance with the outcomes of Gopalakrishna et al. [37], Shukla et al. [38] and Bhutia et al. [30]. However, additive gene effects were also reported for this trait [23,39]. For fruit weight, non-additive gene effects were observed in this study. Contrary to this, Rego et al. [40] observed additive gene effects controlling this trait. In the present study, capsaicin was controlled by non-additive gene effects; previous findings showed that this trait could be governed by either additive gene effects [41] or by non-additive effects [42]. In our study, a high magnitude of non-additive gene effects were expressed for green fruit yield plant ${ }^{-1}$, and this result was in accordance with a previous report [38]. However, the opposite was reported by Rego et al. [40]. Non-additive gene effects are contributing to capsaicin, and it was supported by the findings of Butcher et al. [27].

The cross combination P2 $\times$ P5 was good specific combiner for fruit length, colour value, oleoresin and seed fruit ${ }^{-1}$. The hybrid P4 $\times$ P5 expressed high SCA values for fruit weight, green fruit yield plant $^{-1}$, driage and seed yield fruit ${ }^{-1}$. Similar results were also obtained by Payakhapaab et al. [43]. For days to first flower and fruits plant ${ }^{-1}$, the cross combination P3 $\times$ P4 exhibited high SCA effects. Good general combiners for fruits plant ${ }^{-1}$ was reported by Perez-Grajales et al. [44]. Concerning heterosis, positive heterosis was observed for eight traits and negative heterosis for two traits. The positive and negative heterosis was determined for ten characters. Heterosis over mid-parent has also been reported for fruit traits and yield components in chilli peppers, as well as in other members of the Solanaceae $[15,17,30]$.

Overall, in the present study, non-additive gene effects are predominant for all the studied traits except for fruits plant ${ }^{-1}$ and these traits can be improved through heterosis breeding by exploiting hybrid vigour. Parental P5 was a good general combiner for fruit traits and yield components, followed by parent P4. Parents P5 and P4 were also good general combiners for colour value and oleoresin. Parent P1 was a good general combiner for capsaicin, whereas parent P2 for vitamin C. Based on SCA effects cross combination, P4 $\times$ P5 was an excellent specific combiner for flesh thickness, yield components and vitamin $\mathrm{C}$. The hybrid $\mathrm{P} 2 \times \mathrm{P} 5$ was good general combiners for oleoresin and colour value, whereas the hybrid P1 $\times$ P2 was the best general combiner for vitamin $\mathrm{C}$. These hybrids can be used further in segregation generation analysis, to identify superior stable segregants with high yield and superior quality.

\section{Materials and Methods}

\subsection{Plant Material, Design and Layout}

The materials for the study comprised five parents (Table 6). The five parents were selfed, and they were crossed in a half diallel method to obtain ten F1 hybrids. The hybrids were produced via hand emasculation. Firstly, the well-developed flower-buds likely to open the next morning were emasculated during evening hours and bagged. Later, the buds were pollinated with the male parents (between 08:00 and 10:00) and subsequently bagged with the labelled paper bags. The mature crossed fruits were harvested, and the seeds were collected separately from each cross. For maintenance of parental lines, flower buds of different parents were selfed by bagging the individual buds and properly tagged and later the seeds were collected from the mature fruits accordingly. The experiment was laid out in randomised complete block design consisting of 15 treatments and three replications for two seasons, viz. May 2015 to September 2015 (first season) and October 2015 to February 2016 (second season). Thirty-day-old seedlings having 8-10 $\mathrm{cm}$ height were transplanted into the main field at a spacing of $45 \mathrm{~cm} \times 45 \mathrm{~cm}$. The crop received timely management practices as per package of practices recommendations of Kerala Agricultural University (coordinates at $10.54^{\circ} \mathrm{N}, 76.28^{\circ} \mathrm{E}$ ) 
Thrissur, Kerala, India [45]. The weather information during the crop seasons is provided in Table 7. Further, the soil was sandy loam with a soil pH of 5.8 .

Table 6. Details of parents used for hybridisation.

\begin{tabular}{ccc}
\hline Name of Parents & Accession Number & Source * \\
\hline$P_{1}$ & EC-391083 & NBPGR, Hyderabad \\
$P_{2}$ & EC-596920 & NBPGR, Hyderabad \\
$P_{3}$ & EC-596940 & NBPGR, Hyderabad \\
$P_{4}$ & EC-599969 & NBPGR, Hyderabad \\
$P_{5}$ & Dharwad local-2 & UAS, Bangalore \\
\hline
\end{tabular}

* National Bureau of Plant Genetic Resources (NBPGR), Hyderabad, and the University of Agricultural Science (UAS), Dharwad, respectively.

Table 7. Weather parameters during the first and second crop season.

\begin{tabular}{cccc}
\hline Month & $\begin{array}{c}\text { Average Low } \\
\text { Temperature }\left({ }^{\circ} \mathbf{C}\right)\end{array}$ & $\begin{array}{c}\text { Average High } \\
\text { Temperature }\left({ }^{\circ} \mathbf{C}\right)\end{array}$ & $\begin{array}{c}\text { Average Precipitation } \\
(\mathbf{m m})\end{array}$ \\
\hline May & 27 & Season 1 & 391 \\
June & 24 & 35 & 576 \\
July & 23 & 30 & 391 \\
August & 23 & 29 & 367 \\
September & 24 & 30 & 417 \\
& & 30 & 467 \\
October & 24 & 30 & 223 \\
November & 23 & 31 & 47 \\
December & 21 & 31 & 32 \\
January & 20 & 31 & 26 \\
February & 22 & 32 & \\
\hline
\end{tabular}

\subsection{Morphological Traits}

There were twenty plants in each replication, and the morphological traits were determined from the sample of five randomly selected plants from the three replications. Plant height $(\mathrm{cm})$ and the number of primary branches per plant were recorded at the time of peak harvest. Days to the first flower was estimated based on the average date of transplanting to the first flowering. Days to first harvest (earliness) were determined as the number of days from the date of transplanting to the first fruit harvest.

The total number of fruits produced per plant from all of the plants was counted, and the average was worked out to estimate the total number of fruits per plant. Ten fruits were selected at random from the observational plants to determine the fruit length $(\mathrm{cm})$ and fruit girth $(\mathrm{cm})$. Fruit Weight $(\mathrm{g})$ was recorded as the mean of the representative sample of fruits. Flesh Thickness (mm) was determined as the thickness of fruit pericarp. Flesh to seed ratio was estimated as the ratio of flesh weight/seed weight of fruit from the sample of twenty representative fruits. Seeds per fruit were counted in five fruits, and the average was taken as seeds per plant. Green fruit and dry fruit yield per plant $(\mathrm{g})$ were recorded, an average was worked out and expressed in grams per plant. Yield (kg) was estimated on the per plot basis by determining the fruit harvest of each plot.

\subsection{Fruit Biochemical Traits}

Driage percentage was calculated as the weight change before and after oven drying at $70{ }^{\circ} \mathrm{C}$ based on the formula: $100 \times$ (weight of dried fruit/weight of fresh fruit). For the capsaicin content (\%), the pungent principle (capsaicin) reacts with Folin-Dennis reagent to give a blue coloured complex, which is estimated colourimetrically [46]. In short, an aliquot of $1 \mathrm{~mL}$ was pipetted into $100 \mathrm{~mL}$ conical flask, $25 \mathrm{~mL}$ of Folin-Dennis reagent were added and then it was kept for about $30 \mathrm{~min}$. Afterwards, 
sodium carbonate solution was added with distilled water to make a volume of $100 \mathrm{~mL}$. Next, the optical density was determined at $725 \mathrm{~nm}$ with a spectrophotometer (Jenway, Essex, UK). Oleoresin (\%) was determined with the help of a Soxhlet's apparatus (HMSOX-250, Illinois, United States) and acetone as a solvent. Oleoresin was calculated as the per cent of the weight of oleoresin to the weight of the sample. Ascorbic acid (mg $100^{-1} \mathrm{~g}$ of fresh fruit weight) content of fruit was estimated by 2,6-dichlorophenol indophenol dye method [47]. Firstly, a stock solution was prepared with ascorbic acid $(100 \mathrm{mg})$ in $100 \mathrm{~mL}$ of $4 \%$ oxalic acid. Then, $10 \mathrm{~mL}$ of this stock solution were diluted to $100 \mathrm{~mL}$, with $4 \%$ oxalic acid. Forty-two milligrams sodium bicarbonate were dissolved in a small volume of distilled water. Fifty-two milligrams of 2,6-dichlorophenol indophenol (dye) were added into this and made up to $200 \mathrm{~mL}$ with distilled water. Then, $5 \mathrm{~mL}$ of the working standard solution were pipetted into a $100 \mathrm{~mL}$ conical flask and $10 \mathrm{~mL}$ of $4 \%$ oxalic acid were added. The endpoint of the titration is the appearance of a pink colour, which persisted for at least $5 \mathrm{~s}$. Colour value was determined according to the AOAC procedure [48]. Briefly, red ripe fruits were dried, and the stalk and seeds were removed before powdering. Then, $0.1 \mathrm{~g}$ of ground chilli powder was transferred into a $250 \mathrm{~mL}$ flask with $100 \mathrm{~mL}$ isopropanol and kept overnight at room temperature. The contents were filtered through a Whatman No. 42 filter paper. The first $10 \mathrm{~mL}$ were discarded, and $25 \mathrm{~mL}$ of the filtrate were pipetted into a volumetric flask and diluted with isopropanol. At $450 \mathrm{~nm}$ absorbance with a spectrophotometer (Jenway, Essex, UK), the colour was determined using isopropanol as blank. Standard colour solution was prepared by dissolving $0.5 \mathrm{mg}$ per $\mathrm{mL}$ of reagent grade potassium dichromate into $1.8 \mathrm{M}$ sulphuric acid.

\subsection{Data Analysis}

The analysis for general and specific combining ability and their effects were computed by Method II (parents plus one set of crosses), Model 1 (fixed-effect model), as suggested by Griffing [21], using the AGD-R [49]. Mid parent heterosis was determined as the percentage of increase or decrease of $F_{1}$ hybrids over mid-parent. Pearson's linear correlation coefficients were estimated using the Statgraphics Centurion XVI software program. Mid-parent heterosis was determined based on the formula: $100 \times\left(\left(\mathrm{F}_{1}-\mathrm{MP}\right) / \mathrm{MP}\right)$, where $\mathrm{F}_{1}$ is the hybrid mean and MP is the mean of the parents. The better parent heterosis was estimated as: $100 \times\left(\left(\mathrm{F}_{1}-\mathrm{BP}\right) / \mathrm{BP}\right)$, where $\mathrm{F}_{1}$ is the hybrid mean and $\mathrm{BP}$ is the mean of the better parent.

Author Contributions: S.I. and A.C.S. conceived and designed the project. S.I. supervised the study. A.C.S. and V.S. performed the experiments. A.C.S. and P.K. analysed the data. V.S. and P.K. wrote the paper and corrected the final draft. All authors read and approved the final manuscript.

Funding: This research received no external funding.

Acknowledgments: The authors are thankful to the anonymous reviewers for their careful reading of the manuscript and for providing insightful suggestions.

Conflicts of Interest: The authors declare no conflict of interest.

\section{References}

1. Moscone, E.A.; Scaldaferro, M.; Grabiele, M.; Cecchini, N.; Sánchez García, Y.; Jarret, R.; Daviña, J.; Ducasse, D.; Barboza, G.; Ehrendorfer, F. The evolution of Chili Peppers (Capsicum-Solanaceae): A cytogenetic perspective. Acta Hortic. 2014, 745, 137-169. [CrossRef]

2. Bosland, P.W.; Votava, E.J. Peppers: Vegetable and Spice Capsicums. Peppers 2012, 2, 1-230.

3. Olatunji, T.L.; Afolayan, A.J. The suitability of chili pepper (Capsicum annuum L.) for alleviating human micronutrient dietary deficiencies: A review. Food Sci. Nutr. 2018, 6, 2239-2251. [CrossRef] [PubMed]

4. FAOSTAT. Available online: http://www.fao.org/faostat/en/\#data/QC (accessed on 1 November 2019).

5. Korel, F.; Bağdatlioğlu, N.; Balaban, M.Ö.; Hişil, Y. Ground red peppers: Capsaicinoids content, Scoville scores, and discrimination by an electronic nose. J. Agric. Food Chem. 2002, 50, 3257-3261. [CrossRef] [PubMed]

6. Henry, B.S. Natural food colours. In Natural Food Colorants; Springer: Berlin, Germany, 1996; pp. 40-79. 
7. Prakash, V.; Eipeson, W.E. Post-harvest handling and processing of Capsicums. In Capsicum; CRC Press: Boca Raton, FL, USA, 2003; pp. 183-194.

8. Chattopadhyay, P.; Chatterjee, S.; Sen, S.K. Biotechnological potential of natural food grade biocolorants. Afr. J. Biotechnol. 2008, 7, 2972-2985.

9. Rymbai, H.; Sharma, R.R.; Srivastav, M. Bio-colorants and its implications in health and food industry-A review. Int. J. PharmTech Res. 2011, 3, 2228-2244.

10. Antonious, G.F.; Kochhar, T.S.; Jarret, R.L.; Snyder, J.C. Antioxidants in hot pepper: Variation among accessions. J. Environ. Sci. Health Part B 2006, 41, 1237-1243. [CrossRef]

11. Barrita, J.L.S.; Sánchez, M. Antioxidant role of ascorbic acid and his protective effects on chronic diseases. Oxidative Stress Chronic Degener. Dis. Role Antioxid. 2013, 449, 450-484.

12. Chapa-Oliver, A.M.; Mejía-Teniente, L. Capsaicin: From Plants to a Cancer-Suppressing Agent. Molecules 2016, 21, 931. [CrossRef]

13. Anand, P.; Bley, K. Topical capsaicin for pain management: Therapeutic potential and mechanisms of action of the new high-concentration capsaicin 8\% patch. Br. J. Anaesth. 2011, 107, 490-502. [CrossRef]

14. Jindal, S.K.; Dhaliwal, M.S.; Meena, O.P. Molecular advancements in male sterility systems of Capsicum: A review. Plant. Breed. 2019. [CrossRef]

15. Kaushik, P.; Dhaliwal, M.S. Diallel Analysis for Morphological and Biochemical Traits in Tomato Cultivated under the Influence of Tomato Leaf Curl Virus. Agronomy 2018, 8, 153. [CrossRef]

16. Kaushik, P. Line $\times$ Tester Analysis for Morphological and Fruit Biochemical Traits in Eggplant (Solanum melongena L.) Using Wild Relatives as Testers. Agronomy 2019, 9, 185. [CrossRef]

17. Kaushik, P. Genetic Analysis for Fruit Phenolics Content, Flesh Color, and Browning Related Traits in Eggplant (Solanum melongena). Int. J. Mol. Sci. 2019, 20, 2990. [CrossRef] [PubMed]

18. Aguilar, R.; Quesada, M.; Ashworth, L.; Herrerias-Diego, Y.; Lobo, J. Genetic consequences of habitat fragmentation in plant populations: Susceptible signals in plant traits and methodological approaches. Mol. Ecol. 2008, 17, 5177-5188. [CrossRef] [PubMed]

19. Longin, C.F.H.; Mühleisen, J.; Maurer, H.P.; Zhang, H.; Gowda, M.; Reif, J.C. Hybrid breeding in autogamous cereals. Theor. Appl. Genet. 2012, 125, 1087-1096. [CrossRef]

20. Chaudhary, A.; Kumar, R.; Solankey, S.S. Estimation of heterosis for yield and quality components in chilli (Capsicum annuum L.). Afr. J. Biotechnol. 2013, 12, 6605-6610. [CrossRef]

21. Griffing, B. Concept of general and specific combining ability in relation to diallel crossing systems. Aust. J. Biol. Sci. 1956, 9, 463-493. [CrossRef]

22. Shattuck, V.I.; Christie, B.; Corso, C. Principles for Griffing's combining ability analysis. Genetica 1993, 90, 73-77. [CrossRef]

23. Singh, P.; Cheema, D.S.; Dhaliwal, M.; Garg, N. Heterosis and combining ability for earliness, plant growth, yield and fruit attributes in hot pepper (Capsicum annuum L.) involving genetic and cytoplasmic-genetic male sterile lines. Sci. Hortic. 2014, 168, 175-188. [CrossRef]

24. Geleta, L.F.; Labuschagne, M.T. Estimates of combining ability for agronomic traits in pepper (Capsicum annuum L.). South. Afr. J. Plant. Soil 2006, 23, 73-77. [CrossRef]

25. Naresh, P.; Rao, V.K.; Lavanya Reddy, B.; Anand Reddy, C.; Venkatachalapathi, V.; Madhavi Reddy, K. Genetic analysis for fruit biochemical traits (capsaicinoids and carotenoids) and dry fruit yield in chilli (Capsicum annuum L.). Ind. Crop. Prod. 2016, 94, 920-931. [CrossRef]

26. Rodrigues, R.; Gonçalves, L.; Bento, C.; Sudré, C.; Robaina, R.; Júnior, A. Combining ability and heterosis for agronomic traits in chili pepper. Hortic. Bras. 2012, 30, 226-233. [CrossRef]

27. Butcher, J.D.; Crosby, K.M.; Yoo, K.S.; Patil, B.; Jifon, J.L.; Rooney, W.L. Heterosis in different F1Capsicum annuum genotypes for fruit traits, ascorbic acid, capsaicin, and flavonoids. Sci. Hortic. 2013, 159, 72-79. [CrossRef]

28. Kornegay, J.L.; Temple, S.R. Inheritance and Combining Ability of Leafhopper Defense Mechanisms in Common Bean 1. Crop. Sci. 1986, 26, 1153-1158. [CrossRef]

29. Hasanuzzaman, M.; Hakim, M.A.; Fersdous, J.; Islam, M.M.; Rahman, L. Combining ability and heritability analysis for yield and yield contributing characters in chilli (Capsicum annuum) landraces. Plant. Omics 2012, 5, 337 . 
30. Bhutia, N.D.; Seth, T.; Shende, V.D.; Dutta, S.; Chattopadhyay, A. Estimation of Heterosis, dominance effect and genetic control of fresh fruit yield, quality and leaf curl disease severity traits of chilli pepper (Capsicum annuum L.). Sci. Hortic. 2015, 182, 47-55. [CrossRef]

31. Hundal, J.S.; Dhall, R.K. Breeding for Hybrid Hot Pepper. J. New Seeds 2005, 6, 31-50. [CrossRef]

32. Kempe, K.; Rubtsova, M.; Gils, M. Split-gene system for hybrid wheat seed production. Proc. Natl. Acad. Sci. USA 2014, 111, 9097-9102. [CrossRef]

33. Singh, S.; Dey, S.S.; Bhatia, R.; Kumar, R.; Sharma, K.; Behera, T.K. Heterosis and combining ability in cytoplasmic male sterile and doubled haploid based Brassica oleracea progenies and prediction of heterosis using microsatellites. PLoS ONE 2019, 14, e0210772. [CrossRef]

34. Marame, F.; Dessalegne, L.; Fininsa, C.; Sigvald, R. Heterosis and heritability in crosses among Asian and Ethiopian parents of hot pepper genotypes. Euphytica 2009, 168, 235-247. [CrossRef]

35. Kaushik, P. Application of Conventional, Biotechnological and Genomics Approaches for Eggplant (Solanum Melongena L.). Breeding with a Focus on Bioactive Phenolics. Ph.D. Thesis, Polytechnic University of Valencia, Valencia, Spain, 2019. [CrossRef]

36. Kaushik, P.; Plazas, M.; Prohens, J.; Vilanova, S.; Gramazio, P. Diallel genetic analysis for multiple traits in eggplant and assessment of genetic distances for predicting hybrids performance. PLoS ONE 2018, 13, e0199943. [CrossRef] [PubMed]

37. Gopalakrishnan, T.R.; Gopalakrishnan, P.K.; Peter, K.V. Heterosis and combining ability analysis in chilli. Indian J. Genet. Plant. Breed. 1987, 47, 205-209.

38. Shukla, M.R.; Patel, J.A.; Doshi, K.M.; Patel, S.A. Line $\times$ tester analysis of combining ability in chilli (Capsicum annuum L.). Veg. Sci. 1999, 26, 45-49.

39. Lohithaswa, H.C.; Manjunath, A.; Kulkarni, R.S. Implications of heterosis, combining ability and per se performance in chilli (Capsicum annuum L.). Crop Improv.-INDIA- 2001, 28, 69-74.

40. Do Rêgo, E.R.; Do Rêgo, M.M.; Finger, F.L.; Cruz, C.D.; Casali, V.W.D. A diallel study of yield components and fruit quality in chilli pepper (Capsicum baccatum). Euphytica 2009, 168, 275-287. [CrossRef]

41. Arunkumar, B.; Kumar, S.V.; Hanamashetti, S.I. Genetic variability for phenological and biochemical characters in chilli (Capsicum annuum L.) Genotypes. BIOINFOLET- Q. J. Life Sci. 2013, 10, 495-497.

42. Sarkar, S. Studies on genetic diversity, characterization, yield components and gene action in Chilli. Bidhan Chandra Krishi Viswavidyalaya Mohanpur Nadia West Bengal India 2006, 177, 54-96.

43. Payakhapaab, S.; Boonyakiat, D.; Nikornpun, M. Evaluation of heterosis and combining ability of yield components in Chillies. J. Agric. Sci. (Toronto) 2012, 4, 154-161. [CrossRef]

44. Pérez-Grajales, M.; González-Hernández, V.A.; Peña-Lomelí, A.; Sahagún-Castellanos, J. Combining ability and heterosis for fruit yield and quality in manzano hot pepper (Capsicum pubescens R \& P) landraces. Rev. Chapingo Ser. Hortic. 2009, 15, 103-109.

45. Chilli. Available online: http://www.celkau.in/Crops/Vegetables/Chilli/chilli.aspx (accessed on 12 January 2019).

46. Mathew, A.G.; Lewis, Y.S.; Jagadishan, R.; Nambudiri, E.S.; Krishnamurthy, N. Oleoresin capsicum. Flavour Ind. 1971, 2, 23-26.

47. Manju, P.R.; Sreelathakumary, I. Quality parameters in hot chilli (Capsicum chinense Jacq.). J. Trop. Agric. 2006, 40, 7-10.

48. Zaki, N.; Hasib, A.; Hakmaouia, A.; Dehbi, F.; Ouatmane, A. Assessment of color, capsaicinoids, carotenoids and fatty acids composition of paprika produced from Moroccan pepper cultivars (Capsicum Annuum L.). J. Nat. Sci. Res. 2013, 3, 111-118.

49. Rodríguez, F.; Alvarado, G.; Pacheco, Á.; Crossa, J.; Burgueño, J. AGD-R (Analysis of Genetic Designs with $\mathrm{R}$ for Windows) Version 4.0. Available online: https://data.cimmyt.org/dataset.xhtml?persistentId=hdl: 11529/10202 (accessed on 15 July 2018).

(C) 2019 by the authors. Licensee MDPI, Basel, Switzerland. This article is an open access article distributed under the terms and conditions of the Creative Commons Attribution (CC BY) license (http://creativecommons.org/licenses/by/4.0/). 